\section{A Liquid Commutator for Sinusoidal Currents.}

My attention has been drawn to a note in NATuRE of January IF (p. 253) which quotes from the Electrical World of New York "a novel method of obtaining sinusoidal alternating currents of very low frequency," described by Lieutenant F. Jarvis Patten. The method is to make a pair of conducting plates revolve in a vessel of liquid which also contains a pair of fixed plates. This liquid commutator, however, is not new. It was the subject of a joint patent taken out by Mr. C. G. Lamb and myself a year and a half ago, and it was used in connection with the magnetic curve-tracer in my British Association lecture at Edinburgh on "Magnetic Induction," and again at the Royal Society soirée last May. It has been, in fact, for some time an item in Messrs. Nalder's catalogue of scientific apparatus. A description of it was published in the Electrician of November 18, 1892.

Engineering Laboratory, Cambridge, January 26.

\section{A Curiosity in Eggs.}

A common "barn-door" hen, belonging to a neighbouring farmer, recently laid an egg measuring $4 \frac{1}{2}$ inches in length by 7 inches in circumference; weight 6 ounces. On this egg being carefully broken a second perfect egg, with hard shell of ordinary size ( 3 inches by $5 \frac{1}{2}$ in circumference), was found floating in the contents of the outer one. The contents of both eggs appeared to be normal and healthy. This is surely a very unusual occurrence.

Further Barton, Cirencester, January 16.

E. BRown.

\section{RICHARD SPRUCE, Ph.D., F.R.G.S.}

$A$ LTHOUGH little known beyond a limited circle of $A$ botanists and South American explorers, the subject of this notice was in many respects a remarkable man, who, under more favourable circumstances, would have acquired a wider reputation. He was the son of a schoolmaster at the village of Ganthorpe, Yorkshire, and at an early age showed a taste for botany, having compiled a "List of the Flora of the Malton District" in 1837, when he was just twenty years old. For some years he was teacher of mathematics at the Collegiate School, York ; and during his holidays he explored Eskdale, Teesdale, Killarney, and other districts, paying special attention to the mosses and hepatics, among which he discovered many new species, which he de scribed in the Phytologist, the Transactions of the Botanical Society of Edinburgh, and in the London Journal of Botany. In I 845 he went to the Pyrenees, where he spent ten months, chiefly devoted to his favourite groups of plants, among which he discovered a large number of new or rare species. These were fully described in a paper published in the Annals and Magazine of Natural History in 1849.

The delicate state of his health requiring a warmer and more equable climate than that of his native Yorkshire, he decided, by the advice and with the assistance of the late Sir William Hooker, to visit the Amazon valley as a botanical collector, with the object, if possible, of reaching the head waters of the Orinooko and the eastern valleys of the Andes, districts whose riches had been indicated by the explorations of Humboldt and Bonpland at the beginning of the century, but which no experienced botanical collector had since visited. Invaluable assistance was also given by the late Mr. Bentham, who undertook the great labour of dividing and distributing the dried plants as they arrived in England, and sending sets to those who subscribed for them, thus acting as an unpaid but most efficient agent. The same eminent botanist described most of the new species of flowering plants as they arrived, thus making known the value of the collections, and ensuring the sale of the whole of the specimens.

In July, 1849, Mr. Spruce arrived at Para (where the present writer first made his acquaintance), and during the succeeding fifteen years carried out successfully a series of voyages and explorations in equatorial South Ameriea, surpassing in extent, probably, those of any other scientific traveller. A mere enumeration of these journeys can alone be given here, in order to show how much was accomplished amidst all the difficulties due to climate, scarcity of food, scanty means, and imperfect means of transportation, aggravated by solitude and ill-bealth.

After a few months in Para and its vicinity, he moved to Santarem, at the mouth of the Tapajoz River. Here he remained for a year, collecting and studying the remarkable shrubby vegetation which surrounds the town, consisting largely of species then entirely new to botanists. During this time he made an exploration up the river Trombetas and its tributary the Aripecuru to the limit of canoe navigation. The following year was spent at Manaos (Barra do Rio Negro) exploring the surrounding forests and streams. He next ascended the Rio Negro in a large boat of his own, so as to be able to collect and preserve plants during the voyage. Two months were occupied in ascending the river as far as San Gabriel, situated on the cataracts of the Rio Negro, where he rested seven months, making numerous canoe excursions across the river to the various islands and to tributary streams, not without danger amid the roaring waters produced by the granite rocks and reefs which for some miles here fill the broad river-bed.

Spruce next ascended the Uaupes River as far as the first cataract at Panuré or San Jeronymo, which he made his headquarters for another seven months. Here he was delighted by the richness and novelty of the forest vegetation, which was almost wholly new in species, and even in some of the genera. Many of the loftiest trees had flowers of extreme beauty, especially those of the natural orders Vochysiaceæ, Tiliaceæ, Bombaceæ, Lecythideæ, Rhizoboleæ, and Rubiaceæ, and to add to the botanical interest of the district, when the rainy season brought the flowering of the forest trees to a close, the ground beneath them became ornamented with thousands of curious herbaceous plants, mostly leafless but adorned with delicate or brilliantly coloured flowers. These belonged mainly to the genera Voyria, Burmannia, Ptychomeria, and the Triuridex. Here also fungi were more abundant than in any other locality visited, and about 200 species were collected, many of which were as varied and brilliant in colouring as the flowers themselves.

Leaving the Uaupes the traveller made his next headquarters at San Carlos, the first village in Venezuela situated on the north bank of the Rio Negro, not far from the entrance of the Cassiquiare. From this station excursions were made up the Rio Negro and many of its tributaries, and also through the entire length of the Cassiquiare to Esmeralda on the Upper Orinooko. He was now in the country explored by Humboldt and Bonpland nearly a century before, and collected hosts of plants, which were known only from the specimens sent home by those botanists, together with considerable numbers of new genera and species. In order to procure food in this notoriously hungry region, he made a special journey from San Carlos to the cattle district of the cataracts of Maypures on the Orinooko, travelling over the portage of Pimichin which forms a narrow watershed between the two great river systems. After twenty months in this district he descended again to Manaos, from which he had been absent three years, and prepared for his great journey to the Andes.

Ascending the main stream of the Upper Amazon, and entering its great southern tributary, the Huallaga, he passed beyond its first rapids, and by means of a small western affluent and a day's journey overland, reached Tarapoto. This is a town of about 7000 inhabitants, NO. I 266, VOL. 49] 
beautifully situated in a level plain about 1200 feet above the sea, and almost entirely surrounded by forest-clad mountains of moderate height, from which abundant streams descend through narrow ravines, offering in every direction a rich harvest for the enthusiastic botanist. Here Spruce remained for nearly two years, exploring the country for twenty or thirty miles in every direction, occasionally remaining weeks at a time in the more promising mountain localities. Rich collections of all orders of plants were here obtained, especially of ferns and of his favourite groups the mosses and hepatics, while on the mountains - though only 5000 to 6000 feet in elevation, many north-temperate genera, such as Ranunculus, Rubus, Stellaria, and many others, made their first appearance.

In March, 1857 , he left Tarapoto for the Andes of Ecuador by way of the Upper Amazon and its tributary, the Pastasa, reaching Canelos by a northern branch, the Bobonasa, and thence through the forest to Baños. On the way he had to cross the river Topo by bamboo bridges, constructed afresh by every traveller from rock to rock across the broad mountain torrent. The stream, however, was in flood, and he had to wait four days before the bridge could be constructed, and then the water was so high and the passage so dangerous that most of his baggage--books, manuscripts, microscope, \&c.- - had to be left behind under a thatch of leaves till they could be sent for, his party of sixteen persons being in danger of starvation had they waited longer. After reaching Baños, the packages were sent for, and recovered without injury. During his enforced stay on the banks of the Topo, he had found the forest so rich in plants-especially in his favourite hepatics-that after some weeks he returned there in order to obtain a more complete series of its botanical treasures, and again had the greatest. difficulty and risk in passing the flooded river, of which he declares that the only pleasant recollection he retains is of the new and strange hepaticæ which he collected on its banks.

After some months at Baños, he devoted more than three years to the continuous exploration of the forests and higher mountains of Ecuador, visiting in turn Tunguragua, El Altar, Guayrapata, Azuay, Pichincha, and Chimborazo, but devoting most time to the first named. In the year 1860 he was commissioned by Mr. Clement Markham, on behalf of the Indian Government, to procure seeds and young plants of the Cinchona succirubra, one of the species which produces the best quinine, in order to establish plantations of this precious tree in the Nilghiries. For this purpose he settled himself in the forests on the western slope of Chimborazo, where this species is found between the heights of 3500 and 7000 feet above the sea-level. Assisted by Mr. Robert Cross, a gardener sent for the purpose of taking charge of the plants on the voyage to India, he collected abundance of ripe seeds and raised a quantity of young plants, all of which arrived safely, and helped to form those fine plantations which now supply an abundance of the valuable drug. He also wrote an elaborate report on the Cinchona forests, their vegetation, and the mode of collection and preparation of the bark, which is considered to be one of the best works of its kind that has ever appeared.

This expedition, undertaken and completed under the pressure of almost continual suffering, was the conclusion of Spruce's labours in South America. So long as he had remained in the warm equable climate of the equatorial plains his health had been better than when in England, and appeared to be fairly re-established, notwithstanding much privation and occasional attacks of fever. He suffered, however, from chronic diarrhœa ; and the extremes of temperature and of moisture in the forests and mountains, having frequently to wade for hours in ice-cold water, and exposure to the severe and change- able climate of the high Andes, which, as Mr. Whymper assures us, is the most detestable in the world, brought on an attack of some obscure malarial disease which rendered all further exertion impossible, and led to complications which rendered the remainder of his life that of a confirmed invalid. Under medical advice he removed to the hot and dry sea coast, remaining there for two years in the vain expectation of a recovery sufficient to enable him to extend yet further his botanical explorations.

All hope of renewed health being given up, he returned to England in 1864. After a few months in London, he went to live at Hurstpierpoint, Sussex, in order to be near his correspondent, Mr. William Mitten, who had undertaken to describe the whole of his new South American mosses. After remaining there two or three years, in varying conditions of health, he determined to remove to Yorkshire, where a cottage was offered him on the Castle Howard estate, and where his slender means would enable him to command greater comforts than elsewhere. This was rendered necessary by the loss of a large part of the money derived from the sales of his collections, owing to his having placed it at interest in a commercial house in Ecuador, which, unfortunately, became bankrupt. He was granted a small Government pension in recognition of his services in regard to the establishment of the Indian Cinchona plantations and his complete incapacity for any further remunerative work, and on this and the small remnant of his property he was able to live in some comfort, though with the very greatest economy. He resided first at Welburn and afterwards at Coneysthorpe, both small villages situated near Malton and in the immediate vicinity of the noble park of Castle Howard. Here he lived the life of a confirmed invalid, rarely of late years leaving the house, keeping in a room of uniform warmth and subjecting himself to a rigid system of diet. By these precautions he prolonged his life to the ripe age of seventy-six, and then only succumbed to an attack of influenza, from which his much enfeebled system was unable to rally.

During the twenty-five years of his secluded life in Yorkshire he was always occupied with some botanical work, although for much of the time he could only write or use his microscrope while reclining on a couch. His more important works during this period were his "Palmæ Amazonicæ," forming vol. xi. of the botanical series of the Journal of the Linnean Society, and his "Hepaticæ Amazonicæ et Andinæ," in the Transactions of the Botanical Society of Edinburgh, 1885. During the last few years he published many papers on new Hepaticæ, both American and European, and carried on a considerable correspondence with students of that group in all parts of the world, by whom he was looked up to as one of the greatest, if not the greatest, of living authorities in their favourite study.

Having had the pleasure of Dr. Spruce's acquaintance from the time when he reached Para in 1849-an acquaintance which soon ripened into friendship during the many days spent together in various parts of the Amazon and Rio Negro, in London, at Hurstpierpoint, and during several visits to him at Welburn and Coneysthorpe-a few words descriptive of his appearance and character may not be out of place. Richard Spruce was tall and dark, with fine features of a somewhat southern cast, courteous and dignified in manner, but with a fund of quiet humour which made him a most delightful companion. He possessed in a marked degree the faculty of order, which manifested itself in the unvarying neatness of his dress, his beautifully regular handwriting, and the orderly arrangement of all his surroundings. Whether in a native hut on the Rio Negro, or in his little cottage in Yorkshire, his writing materials, his books, his microscope, his herbaria, his stores of food and clothing, all 
had their appointed places in which they were always to be found. This habit of order made him an admirable collector, and I well remember, on visiting Kew after my return from the Amazon, the late Sir William Hooker took out some bundles of plants collected by Dr. Spruce and pointed out to me how well chosen and beautifully preserved they were, notwithstanding that they had been collected in one of the very moistest climates in the world, in which the care and labour required to produce such a result was very great. He was quick at languages; spoke and wrote French with ease ; and in South America rapidly acquired the Portuguese and Spanish languages, for the latter of which he had a great admiration. He had literary tastes, and was fond of the old poets ; he was full of anecdote, and even when suffering from illness an hour would rarely pass without some humorous remark or pleasant recollection of old times. He was an advanced Liberal in politics, a true lover of the working classes, and nothing more excited his indignant wrath than to hear of the petty, but cruel, persecutions to which they are often subjected. In all his words and ways he was a perfect gentleman, and to possess his personal friendship was a privilege and a pleasure.

Of his merits as a botanist it must be left to experts to speak; but his writings show that he had great powers of observation, and that nothing escaped him that could throw light on the peculiarities of the grand and luxuriant vegetation among which the best years of his life were passed. His papers and letters sufficiently prove that he possessed a clear and picturesque style of writing, and it is to be hoped that the journals kept during his fifteen years' exploration, which he was himself unable to prepare for publication but which must be full of interesting matter, may soon be given to the world. His sole executor is his old friend and neighbour, Mr. Matthew B. Slater, of Malton.

A. R. W.

\section{PRECIOUS STONES.}

$\mathrm{O}^{\mathrm{N}}$ NLY twenty-five years have elapsed since the existence of diamonds in South Africa was first made known, and during that period the diamond trade of the world has undergone a complete revolution. The working of diamond gravels in Brazil has been almost entirely abandoned, while the search for the gem in India, Borneo, and other districts has been seriously discouraged. The export of rough diamonds from South Africa rose gradually from 200 carats in $1867-68$ to $3,841,937$ carats in 1888 , when it attained a maximum: since that date, bowever, there has been a slight decline in the output of the mines. The annual value of the diamonds raised in South Africa now exceeds $£ 4,000,000$. Strange to say, the discovery of the new and abundant source of diamonds has not had any serious effect in diminishing the market value of the gem. When the diamond was first discovered in South Africa, the estimated value per carat of the rough stones was about $£$ I IOS.; in I 890 the price had risen to $£ \mathrm{I} \mathrm{I} 3 s .3 d$., and last year it declined to $£$ I $5 \mathrm{~s} .8 \mathrm{~d}$.

The foregoing particulars are taken from a recently published book which gives an admirable account of the origin of the diamond industry in South Africa, and of the successive changes made in the method of mining and washing the "blue-earth" which yields the gems. ${ }^{1}$ This work originally appeared as a guide to the Kimberley exhibition of 1892 , and contains so much valuable information in a small compass, that the author has been well-advised in issuing it in its present more permanent form.

1 "Diamonds and Gold in South Africa." By Theodore Reunert, M.Inst.M.E., Assoc. M.Inst.C. E., with Maps and Illustrations. (London: E. Stanford; and Capetown, Port Elizabeth, and Johannesburg: J. C. Juta and Co., r893.)

$$
\text { NO. I } 266 \text {, VOL. 49] }
$$

The working of the celebrated mines about Kimberley was commenced by adventurers working independently in their claims. But as the mining was carried to greater and greater depths, combined action became necessary, and gradually the claims were amalgam ated and bought up by large companies.

Up to the year 1872 the working of the claims in the South African mines was carried on by a system of roadways, which were laid out when the concessions were first granted. About the date named, the use of these roads had to be abandoned in favour of a system of haulage by wire ropes-these making a network over the whole of the mines. The appearance of the mines under these two systems of working is admirably illustrated by photographs in the work before us. By the year $18 \delta 4$, the mine at Kimberley having been carried to a depth of 400

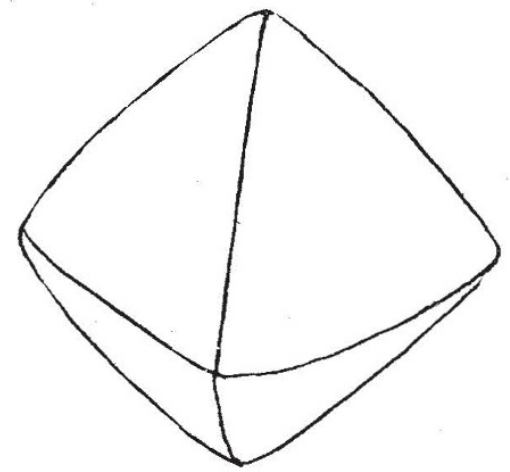

Exact size and shape of a diamond found in the De Beers Mine, and exhibited at the Paris Exposition, x889. Weight, before cutting, 428 carats, after cutting, $228 \frac{1}{2}$ carats.

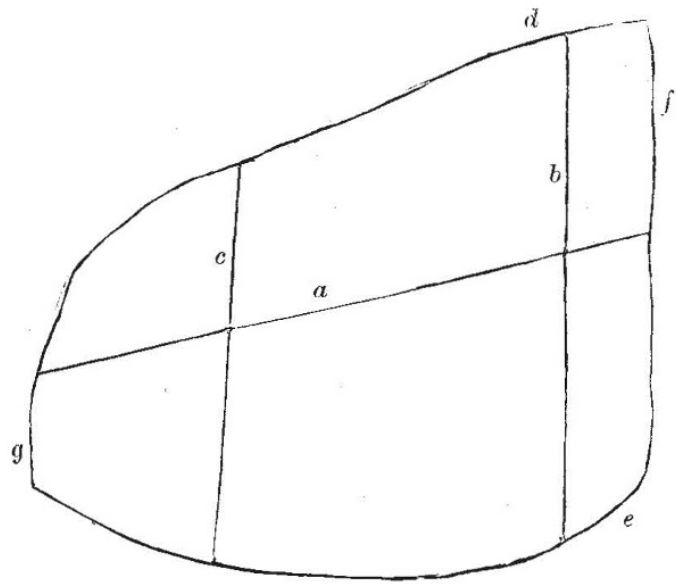

Diamond found in Jagersfontein Mine in June 1893 . Length $(a) 2 \frac{1}{2}$ in.; greatest width $(b) 2$ in.; smallest width $(c) 1_{2} \frac{1}{2}$ in. Thickness at $(b)$ end $1 \frac{1}{4}$ in.: thickness at $(c)$ end $\frac{7}{8}$ in. Extreme girth in width (taken from $e$ to $d$ ) $5 \frac{3}{8}$ in. Extreme girth in length (taken from $f$ to $g$ ) $6_{4}^{3}$ in. Gross weight $969 \frac{1}{2}$ carats.

feet, and heavy falls of material having produced serious loss and inconvenience, it was felt that the time had come for carrying out a totally different system of mining there. Accordingly, in that year, inclined shafts, starting from the surface, outside the limits of the mine, were put down, and these inclined shafts have been since superseded by vertical ones.

The changes in the working of the Kimberley Mine have been followed by similar alterations in the nature of the operations carried on in the three other great mines in its immediate neighbourhood-De Beers, Bultfontein, and Dutoitspan. These four mines are in the vicinity of the townships of Kimberley and Beaconsfield in the British colony of Griqualand West. The only other im- 